\title{
EVALUASI MEREK BANGSA “ULTIMATE IN DIVERSITY" DALAM KAMPANYE PEMASARAN PARIWISATA
}

\author{
Romeyn Perdana Putra \\ Pusat Penelitian Pengembangan Kebudayaan Badan Penelitian dan \\ Pengembangan \\ Kementerian Pendidikan dan Kebudayaan Republik Indonesia \\ Pos-El: romeyn.perdana@gmail.com
}

\begin{abstract}
ABSTRAK
Penelitian ini mengevaluasi satu kebijakan merek bangsa (nation brand)- Ultimate in Diversity (UiD). Implementasi merek bangsa menghadapi tantangan terkait kebijakan. Sasarannya adalah untuk mengevaluasi kebijakan UiD dalam area manajemen pemasarannya. Metodologi penelitian yang digunakan adalah analisis interpretasi-naratif berdasarkan hasil wawancara mendalam, diskusi kelompok terarah dan data sekunder. Ulasan ini menjabarkankan temuan bahwa terdapat kesenjangan antara perencanaan dengan kondisi aktual yang ada dilapangan. Pertama, tidak terproyeksikannya mantra kampanye "Ultima dalam perbedaan" dalam kehidupan sehari-hari di Indonesia. Kedua, masih sulitnya sinergi kampanye antara pusat dan daerah dalam merek bangsa.
\end{abstract}

Kata kunci: Kebijakan Ultimate in Diversity, Merek Bangsa, Evaluasi Pemasaran 


\title{
BRAND EVALUATION OF THE NATION "ULTIMATE IN DIVERSITY" IN TOURISM MARKETING CAMPAIGN
}

\begin{abstract}
This study is evaluating a nation brand policy. Nation branding in this case study was having constraints in implementation. Methodology is qualitative with interpretative-narrative analysis based in indepth interview, Focus Group Disscusion (FGD) and secondary data. Findings of this research are two constraints of implementing this campaign. This study is aiming at tourism marketing management in communicating UiD. First, mantra campaign of "Ultimate in Diversity" is not projected in daily life. Second, sinergy constraint among center dan province in campaigning Nation Brand.
\end{abstract}

Keywords: Ultimate in Diversity, Nation Brand, Marketing Evaluation

\section{PENDAHULUAN}

Instruksi Presiden Republik Indonesia Nomor 16 Tahun 2005 Tentang Kebijakan Pembangunan Kebudayaan Dan Pariwisata telah menggariskan kebijakan yang jelas tentang adanya kampanye / promosi mengenai Indonesia Ultimate in Diversity. Inpres ini bermaksud memberikan pelayanan kepada wisatawan baik dalam dan luarnegri untuk lebih mengenal Indonesia sebagai bangsa dengan tingkat keberagaman ultima (ultimate) dalam kebudayaan dan pariwisata. Dalam Inpres No. 16 tahun 2005 ini terdapat poin khusus disposisi kepada Kementrian Pendidikan Nasional (poin 2 instruksi khusus) agar kementerian meningkatkan pendidikan bermuatan sejarah nasional, kepribadian, akhlak mulia dan multikultural. Terdapat pula disposisi kepada 20 kementerian dan lembaga pemerintahan ditambah poin ke-21 kepada seluruh gubernur, bupati dan walikota untuk melaksanakan inpres ini. Pada tataran kebijakan pembangunan kebudayaan dan pariwisata hal ini terkait kondisi lokal, regional dan global. Pemerintah telah melansir kebijakan ini satu dekade lalu. Perlu ditinjau kembali apakah kebijakan ini telah tepat sasaran menghadapi tantangan global yang dihadapi kedepan. Permasalahan terorisme, wabah penyakit menular dan bencana alam menjadi momok tumbuh dan berkembangnya pariwisata Indonesia layaknya jaman keemasan ketika menjadi primadona penerimaan devisa negara.

Globalisasi telah mewajibkan negaranegara dunia untuk mendeklarasikan dirinya sebagai negara yang telah memiliki standar hidup yang sama dengan negara lainnya. Gunawan Muhammad dalam Catatan Pinggir memberikan contoh bagaimana perbatasan antar negara, layaknya sejarah Westphalia, semua berujung kepada kedaulatan negara (sovereignity). Dimana perbatasan negara pada suatu saat hanyalah permasalahan keimigrasian (baca: "kedaulatan", sesuai tugas pokok dan fungsi keimigrasian pada Undang-undang No. 6 tahun 2011 tentang Keimigrasian). Ketika semua bangsa bersama-sama berusaha menyamakan 
kualitas hidup dan standar hidupnya, dikutip dari Cromwell (2007), yang menyebutnya sebagai dunia dimana negara-negara berusaha menjadi seragam dalam hal-hal infrastruktur dan kualitas hidup. Perkembangan kebijakan di Indonesia juga ditandai dengan bergulirnya UU No. 22 dan No. 25 tahun 1999. Sebagaimana dikutip dari Riwanto, pemerintah pusat telah mendelegasikan wewenangnya kepada pemerintah daerah atau Otonomi daerah. Riwanto juga menggarisbawahi pemekaran provinsi, kabupaten, kecamatan dan desa-desa baru. Pada tulisannya Riwanto mengamati permasalahan hubungan pusat dan daerah yang berkembang di daerah Buton.

Kebijakan di dalam negeri yang berkembang memiliki hubungan yang menarik bila disandingkan dengan Merek Bangsa (Nation Brand). Ultimate in Diversity (seterusnya dapat tertulis dengan akronim : UiD) dalam kiprahnya secara lokal, regional dan global dapat dikatakan telah menjadi persoalan manajemen pemasaran. Evaluasi disini diulas dalam perspektif alur proses pembentukannya, dilanjutkan dengan evaluasi keberhasilan dan atau kegagalannya, sehingga didapat rekomendasi apakah kebijakan layak dilanjutkan/ direvisi atau malah dihentikan. Menggunakan model evaluasi yang dikembangkan oleh Ernest R. Alexander dalam Aminudin (2007), ${ }^{3}$ yaitu Actual versus Planned performance comparison. Metode ini menggali obyek penelitian dengan membandingkan antara pencapaian yang diharapkan (planned) dengan kondisi aktual di lapangan. Pakar merek (branding) berpendapat bahwa nation brand hanya mungkin obat mujarab untuk negara-negara lebih kecil dan miskin dengan menggarisbawahi keunggulan kompetitif-nya di pasar global (Anholt, 2003,2007, Dinnie, 2008; Ollins, 1999;. Papadopolous dan Heslop 2002 dalam Kaneva et al, 2011). Sehingga dalam paradigma fungsionalis / atau paradigma non-politis, strategi pemasaran ini lebih berpendapat bahwa merek bangsa menawarkan pendekatan ramah pasar (market friendly approach) dengan tata kelola yang melampaui paradigma politik.

Sebaliknya, Varga (2013) memiliki perspektif yang berbeda dalam paradigma nonpolitis dari merek bangsa. Ia berpendapat bahwa merek bangsa dapat menjerumuskan diri sendiri dan mem-bahayakan proses demokrasi. Varga ingin menggarisbawahi fenomena baru dari merek bangsa sebagai area identitas politik dan sebagai langkah-langkah kebijakan budaya. Kebijakan budaya dalam pemerintahan adalah sistem yang disempurnakan dari nilai-nilai, pemahaman dan sikap yang diwujudkan dalam praktek-praktek sosial. Tagline atau sampiran judul diberikan kepada identitas pribadi dan melekat ke suatu komunitas masyarakat tertentu. Terlepas dari semua argumen, branding dalam aplikasi yang sering ditemukan; diterapkan untuk berbagai barang konsumen atau produk nyata (tangible product). Saat ini perkembangan penerapannya juga diaplikasikan untuk berbagai industri jasa dan tempat (kota, negara dan daerah tujuan wisata).

Merek-merek pada produk komersial seperti barang berwujud (tangible) dapat dihentikan, dimodifikasi, ditarik dari pasaran atau dinonaktifkan, kembali dipasarkan(diluncurkan kembali, reposisi dan diganti produk) dengan produk yang lebih baik. Tapi hal ini sulit dilakukan kepada tempat dan merek bangsa, pilihan ini sering tidak tersedia untuk produk intangible. Karena merek bangsa tidak 
menawarkan penawaran nyata, atribut mereka sulit untuk ditafsirkan dan dijelaskan. Menurut Yin Fang (Brunel Business School: 2005) yang ditawarkan oleh branding adalah hubungan emosional daripada hubungan fungsional. Permasalahan muncul adalah bagaimana ulasan terhadap kebijakan tersebut dikaitkan dengan isu kontemporer. Didalam negeri kebijakan pemerintah mengajak warganya untuk lebih menghargai keaneka beragaman budaya bangsa. Ke luar negri, negara berusaha untuk memproyeksikan diri sebagai negara dengan 17.000-an lebih pulau, dengan lebih dari ribuan bahasa, cakupan flora-fauna tiada habisnya, kuliner dalam berbagai rupa sajian dan budaya suku bangsa dari sabang hingga merauke. Yang bila diperbandingkan hanya bisa dikalahkan oleh perkumpulan negara-negara Benua Eropa menjadi satu. Secara lebih eksplisit, penelitian ini ditujukan untuk:

1. Mengkaji nilai-nilai strategis dan filosofis kebijakan merek bangsa "Ultimate in Diversity".

2. Mengulas implementasi proses pembentukan kebijakan merek bangsa, kondisi aktual di masyarakat dan kesenjangannya terhadap perencanaan merek bangsa.

3. Mengkaji pengaruh kebijakan UiD terhadap daya saing pariwisata nasional dibandingkan dengan pariwisata regional dalam hal ini ASEAN.

Untuk memberi batasan diskusi dalam ulasan ini, konsep merek bangsa diadopsi definisi sebagai berikut: 'Merek bangsa yang menitik-beratkan kepada kebijakan Inpres no 16 tahun 2005 yaitu Ultimate in diversity berikut dengan turunan merek bangsa yang mengikuti kampanye promosinya seperti Wonderful

Indonesia 2014'.

\section{METODE PENELITIAN}

Penelitian ini menggunakan metode deskriptif untuk menggambarkan identifikasi data penelitian yang diperoleh berdasarkan kriteria tertentu. Pengumpulan data menggunakan FGD dan wawancara mendalam. FGD awal dilakukan di Jakarta dengan narasumber dari akademisi dan budayawan pada bulan September dan Oktober 2014 di Jakarta. FGD juga dilakukan di Pulau Buton Kota Bau-bau dengan dinas pendidikan dan kepala sekolah SD, SMP dan SMA.Pemilihan Baubau sebagai lokasi lebih kepada alas an keberagaman, perbedaan bahasa dan dari segi kepraktisan (karena pada saat dinas penulis bertemu dengan anggota keluarga Kesultanan Buton lapis ketiga). Selain FGD juga dilakukan wawancara mendalam dengan penggiat kebudayaan atau tokoh

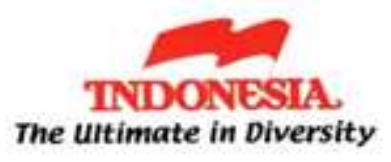


budaya, staf peneliti Balitbang Kemenpar dan wisatawan asing (pelaju berasal dari Italia bermaksud untuk melaksanankan perjalanan bisnis). Teknik analisis adalah interpretatif-naratif yaitu peneliti menafsirkan secara bebas wacana yang dikembangkan. Sedangkan untuk data sekunder peneliti mendapatkan data hasil evaluasi merek bangsa yang telah dilakukan kemenpar pada tahun 2010 dan hasil observasi, studi pustaka / dokumentasi, buku, layaran internet, dan media massa cetak maupun elektronik. Dengan sasaran penelitian yang bertujuan untuk mengkaji kebijakan dibidang pemasaran pariwisata dan evaluasinya. 


\section{HASIL DAN PEMBAHASAN}

\section{a. Nilai Strategis Dan Filosofis Kebijakan Uid}

Secara emosional tentu kita pernah mendengar bahwa banyak turis asing lebih mengenal Bali daripada Indonesia itu sendiri. Sehingga perlunya dibuat kebijakan mengenai tema promosi (kampanye) Ultimate in Diversity diluncurkan dengan program pemerintahan seperti Visit Indonesia year 2008. Kampanye

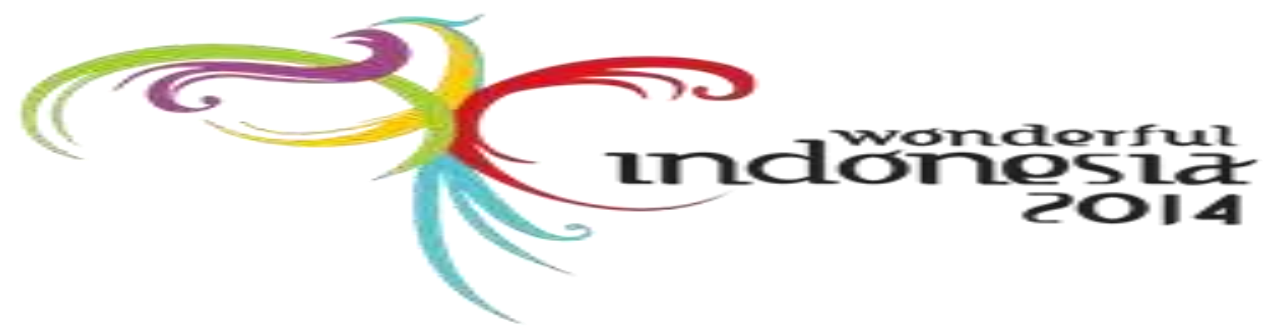

"KenaliNegerimu Cintai Negerimu Ayo Tamasya Jelajahi Nusantara" untuk menjaring kesadaran wisatawan domestik untuk lebih menyukai wisata di dalam negeri. Hingga yang terbaru Wonderful Indonesia 2014, sebagai program yang baru dilancarkan, sebagai turunan dari kebijakan UiD, Merek Indonesia di desain oleh kementerian Pariwisata, adalah dengan maksud promosi dan kampanye merek bangsa. yang diadopsi dalam desain kampanye Ultimate in Diversity, Wonderful Indonesia dan filosofi Bhinneka Tunggal Ika:

Gambar 1. Transformasi Garuda Pancasila menjadi Logo Pemasaran

Konsep Garuda Pancasila dalam desain kampanye ini mengadopsi cara pandang hidup bangsa dengan pendekatan modern dan lebih berwarna (hasil wawancara dengan pejabat pusat data dan informasi). Adapun konsep simbolisasinya adalah sebagai berikut:

a. 5 (lima) norma menggambar dengan 5 garis berwarna yang berbeda dan melambangkan Indonesia Unity

Diversity. 
b. Merek logo ini dirumuskan menjadi sosok yang dinamis dan warna sebagai implementasi Dinamis Indonesia yang berkembang. Desain tulisan

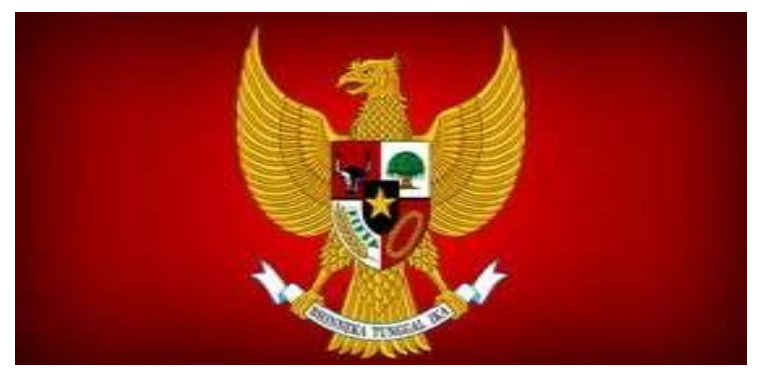

yang dinamis dan bercirikan unsur-unsur Indonesia dengan pendekatan modern (non traditional). Sumpah Pemuda 28 Oktober 1928 memiliki deklarasi yang menyatakan sumpah bahwa: Indonesia sebagai satu bangsa, satu tanah air dan satu bahasa: Indonesia. Namun hal itu tidak disebutkan Indonesia sebagai satu budaya. Keanekaragaman dalam Bahasa, warna kulit, agama, dalam bentuk pluralisme / yang disebut Bhinneka Tunggal Ika.

Satu pertanyaan sederhana: "Quo Vadis pariwisata Indonesia?" Untuk jawaban cepat, kesimpulannya adalah: menteri pariwisata ingin mengurangi kemiskinan, meningkatkan investasi asing, menyerap tenaga kerja dan mengembangkan ekonomi. Alm. Joop Ave menjelaskan Visi dan Misi pada pengembangan Pariwisata. Landasan pariwisata dirancang dari filsafat Pancasila.

Filosofi Pariwisata Indonesia didasarkan pada salah satu nilai-nilai agama, yang disebut "keseimbangan hidup" (disebut: tiga prinsip kebahagiaan) yang terdiri dari (Almarhum Joop Ave, pada Kuliah Umum di wisuda STP SAHID, September 2006):

a) Hubungan Keseimbangan antara manusia dan Tuhan,

b) Hubungan Balance di antara manusia itu sendiri (individu dengan individu, individu dengan masyarakat, orangorang dengan orang-orang),

c) Hubungan Keseimbangan antara manusia dan lingkungannya.

Berdasarkan filosofi ini, beberapa prinsip dasar pariwisata Indonesia yang disusun sebagai berikut :

a) Manusia (people) adalah pusat atau menjadi subyek pariwisata, bukan objek.

b) Semua ciptaan orang (tangible dan intangible) dan hubungan antar antara orang-orang urusan kebudayaan. Pada dasarnya perkembangan mereka kreasi yang merangsang gerakan (perjalanan) dari orang-orang wisata budaya.

c) Orang (masyarakat) adalah kekuatan (competitive advantage) dari wisata budaya.

d) Pariwisata harus berbasis masyarakat (dari rakyat, oleh rakyat, untuk rakyat) community-based tourism.

e) Mengambil manfaat (eksploitasi) dari budaya dan alam harus diimbangi dengan pelestarian dan konservasi budaya dan alam itu sendiri. Dengan 
kata lain; harus ada rasa kontrol diri atau tidak menjadi serakah (hanya mengeksploitasi) prinsip pariwisata berkelanjutan .

Dari paparan diatas jelas bahwa pemerintah memiliki tujuan pencapaian hasil dari kampanye ini adalah lebih kepada rencana filosofis dan strategis. Sebuah proses penentuan bagaimana kebijakan ini dipilih, dalam memasarkan bangsa diperlukan kebijakan yang tidak hanya memiliki fungsi pasar. Namun juga memiliki makna filosofis dan strategis tentang bagaimana kebijakan itu dipilih. Bahasan berikut akan menggarisbawahi ulasan implementasi dari kebijakan UiD ini.

\section{b. Implementasi Kebijakan Uid Perspektif Praktisi Pariwisata}
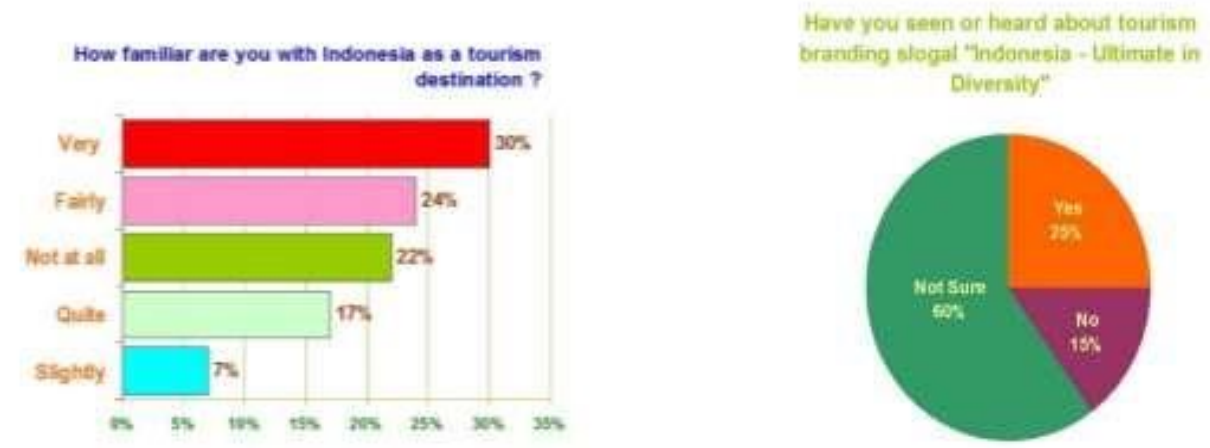

Sumber: Kementerian Pariwisata (2010)

Gambar 2. Brand Awareness (tingkat kesadaran akan merek) Praktisi Pariwisata terhadap merek Bangsa UiD 
Kementerian Pariwisata telah melakukan evaluasi merek bangsa dengan suatu penelitian. Teknik pengumpulan data yang digunakan adalah menyebarkan kuesioner kepada 33 ahli wisata internasional dari berbagai negara. Responden tersebut dipilih secara purposive sampling, profesional di bidang pariwisata, pemangku kepentingan pariwisata internasional dari sektor swasta dan publik. Dua aspek penting dari evaluasi tersebut meliputi: pertama, secara umum responden menyadari bahwa Indonesia sebagai daerah tujuan wisata (DTW). Namun bila disandingkan dengan jawaban kedua, apakah pernah melihat ataupun mendengar slogan "Indonesia-UiD"? jawaban "tidak pasti" ditemukan. Pada data ini mencerminkan bahwa evaluasi merek bangsa adalah moderat dalam menghasilkan kesadaran merek (brand awareness). Ketertinggalan Indonesia, menurut sumber dari Peneliti Kemenpar adalah kurang ear catching-nya Ultimate in Diversity dalam penyebutan dan pemaknaannya oleh wisatawan.

Masih dalam evaluasi yang dilakukan oleh Kemenpar mengenai evaluasi merek bangsa UiD, penelitian juga menggali persepsi dan keampuhan merek untuk menarik wisatawan datang. Merek memiliki "apeal" atau daya tarik dan "encouraging" atau daya rangsang kepada calon pembeli untuk membeli. Berikut ini diagram keluaran dari hasil olahan evaluasi merek terkait daya tarik.
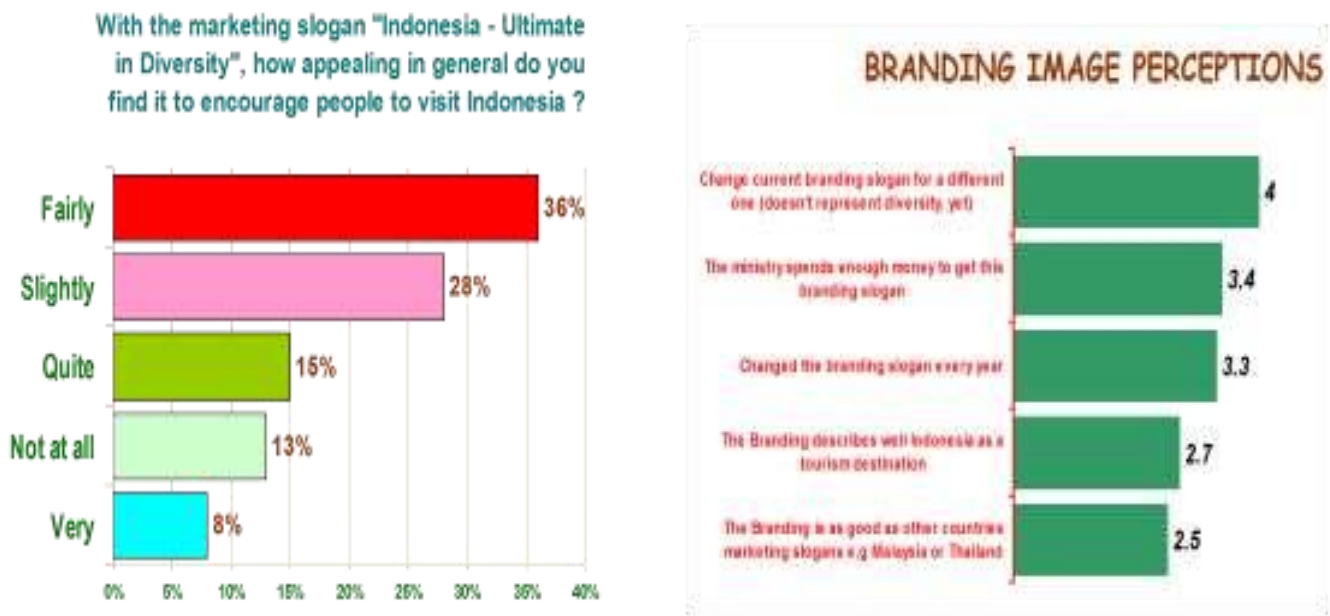

Sumber: Kementerian Pariwisata dan Ekonomi Kreatif 2010

Gambar 3. Persepsi responden terhadap Merek UiD

Data ini mengevaluasi merek bangsa sebagai suatu kebijakan yang perlu diganti karena tidak dipresentasikan (belum), dalam kehidupan masyarakatnya. Daya tariknya sendiri masih digolongkan lemah untuk merangsang wisatawan datang. Sebuah merek yang sukses akan mewujudkan, terproyeksikan dan mewakili 
unsur-unsur positif yang beragam dari keseharian dan ingredients atau lokal identitas yang melekat kedalam bangsa tersebut.

Pada rentang tahun 2000 hingga 2005, sebelum kebijakan Inpres mengenai UiD diterbitkan, Indonesia mengalami kemunduran sektor pariwisata. Dimana Ancaman terorisme (Bom Bali I dan II), fobia penerbangan akibat penyakit menular (SARS, Flu Burung, H5n1). Diperparah dengan beruntunnya Indonesia mengalami bencana alam tiada henti (Tsunami, Gunung Meletus, banjir) . Letak Indonesia yang berada dalam 'cincin api', lempeng gunung aktif yang mengelilinginya (Indonesia 'ring of fire'). Sehingga berbagai kebijakan disektor pariwisata dianggap inefisien untuk ditetapkan karena tidak didukung kondisi dalam negeri dan luarnegeri kondusif. Keterpurukan ini tentunya tidak bisa dibiarkan berlarut-larut. Pemerintah Indonesia telah mencoba memberikan berbagai insentif kepada sektor riil. Penerbangan dalam negeri berkembang pesat dengan dibukanya kemudahan ijin perusahaan penerbangan berbiaya murah (Airline low cost carrier). Hotel-hotel juga tetap dibangun, walaupun dalam beberapa episode pemerintah asing memberikan travel warning bagi warganya untuk berkunjung ke Indonesia (Australia dan Inggris yang mengeluarkan peringatan bagi warganya untuk berwisata ke Indonesia).

Setelah bergulirnya Inpres no. 16 (tahun 2005), lalu pada tahun 2008, pemerintah mencanangkan Visit Indonesia Year 2008. Dimana berkait dengan bergulirnya Travel warning, Travel advisory dan Travel notice, pemerintah menggalakan program berwisata kepada wisatawan domestik (wisdom) dan wisatawan mancanegara (wisman) untuk menjadikan tahun 2008 sebagai tahun kunjungan ke Indonesia. Pada masa itu dalam kalender hari libur nasional bersamaan dengan libur akhir pekan. Sehingga banyak wisdom memanfaatkan penerbangan murah dan insentif pariwisata dalam negeri.

\section{c. Implementasi di Daerah}

Tanggung jawab untuk mempromosikan dan regulasi pariwisata secara tugas pokok dan fungsi terletak pada pelayanan kementerian pariwisata masingmasing provinsi memiliki sendiri kantor pariwisata desentralisasi mereka di bawah pemerintah provinsi (Pemerintah daerah-PEMDA). Pemerintah pusat melalui kemenpar mengatur kebijakan terpusat dan perencanaan di bidang pariwisata. Termasuk salah satu kota Bau-bau yang berada di Pulau Buton. Dulunya pulau ini terdapat kejayaan Kesultanan Buton. Dari kota Baubau Buton terdapat aksara Ciacia yang mengadopsi huruf hangul (Korea) dan beragam bahasa dan suku beragam. Dikutip dari narasumber di Kota BauBau Buton hasil wawancara menyatakan bahwa sesuai dengan nawa/cita Presiden Jokowi cita kedelapan yaitu menumbuhkan karakter bangsa, disamping patriotisme dan meneguhkan kebinekaan. Ada fakta bahwa selama ini kebudayaan terkikis oleh globalisasi.

Masih menurut salah satu narasumber dari Baubau: Anak-anak muda Baubau yang merantau ke kota besar seperti Jakarta dan Surabaya, ketika pulang berubah gaya bahasanya dan tragisnya mereka banyak yang melupakan tradisi budaya daerahnya. Sepertinya ada fakta bahwa orang sudah tidak mau tahu 
dengan budayanya sendiri. Pada awal sejarahnya, dikutip dari seorang narasumber, terdapat 72 bahasa Baubau dan 5 bahasa inti. Bahasa inti itu adalah wolio, pulo wakatobi, pancana, busel dan buton. Dalam kesehariannya sudah tidak digunakan lagi bahasa daerah. Bahasa wolio untuk bahasa sehari-hari saat ini sedang mengalami kemunduran luar biasa, karena banyak yang sudah tidak bisa berbahasa Wolio lagi. Bahasa sudah terkikis, dan dialek Jakarta sudah mulai dipakai. Baubau yang dulunya merupakan pusat kerajaan Buton, bahkan dulunya memiliki mata uang sendiri yang namanya Kampua. Hal ini menunjukkan bahwa Baubau sedari dulu sudah mempunyai identitas budaya dan karakter yang jelas dan mandiri. Simbolkultural masyarakat Buton terletak kepada simbol keraton (beserta sisa bentengnya), bangunan masjid/tradisi upacara keagamaannya, bangunan makam sultan dan terakhir museum wolio. Simbol ini menjadi pengikat lokal identitas Kesultanan Buton masa lalu. Semangat ini selayaknya terus dilestarikan, bukan dengan terjemahan bahwa lestari sebagaimana layaknya keagungan masa lampau.

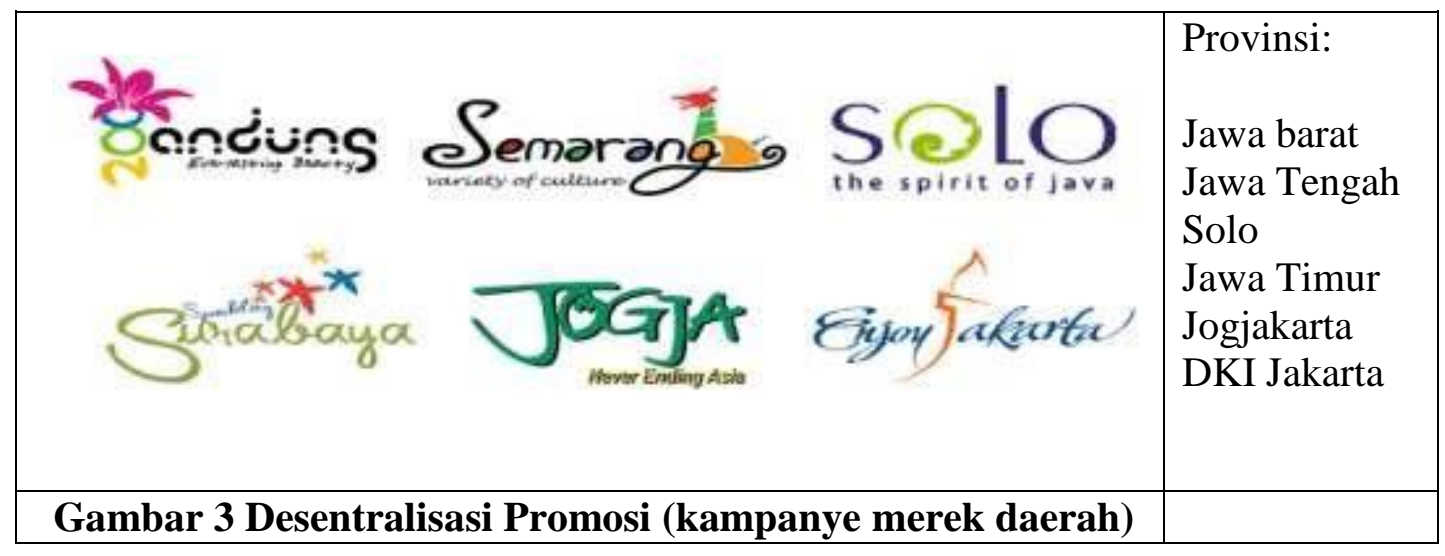

Beberapa kekhawatiran dari tinjauan teori sebelumnya, yang menyatakan bahwa paradigma merek bangsa adalah sifatnya politis dan membangkitkan sentimen eksklusifitas. Perbedaan adalah aset yang ditekan dengan visi yang dikembangkan para founding fathers: pancasila dengan kampanye payungnya yang mengadopsi Ke-bhineka Tunggal Ika-an. Riwanto dalam buku "Mencari Indonesia" jilid 2 (2010), merujuk kepada disintegrasi politik budaya dengan adanya pemekaran wilayah yang sejatinya adalah lebih mengecilkan area administrasinya ke wilayah yang lebih kecil (semangat pemekaran adalah mengkotakkan wilayah menjadi lebih kecil dari inti awal daerah). Dalam tulisannya Riwanto menyatakan keinginan pemekaran lebih kepada kekuasaan (auhority) dengan dasar legal formal (halaman 247), tanpa menangkap bahwa merek daerah adalah simbolik-kultural. Maknanya, terdapat kegagalan daerah untuk menimbang konflik yang akan menjadi ikutan dari kekuasaan pemekaran tersebut. Bahwa nama (merek) suatu lokalitas tertentu memiliki hubungan dengan identitas kolektif masyarakatnya. Sehingga berbeda dengan Bali dimana 
masyarakat yang mendominasi sangat terbuka terhadap pluralisme. Bali memiliki homogenitas identitas kolektif budaya, agama dan bahasa seragam.

Sebuah merek bangsa seyogyanya mewajibkan produk unggulan dan prima menjadi ikutan (sub merek atau varian) pada varian-varian merek yang mengikutinya. Dalam hal ini keberagaman diterjemahkan dalam hal beraneka bentuk dan pakem. Ego sektoral dalam membentuk merek menjadikan pemasaran merek bangsa menjadi partial atau terlepas dari akar pokok pohon utamanya. Varian-varian per kota / kabupaten menjadi eksklusif terhadap tempatnya. Tak berjenjang terhadap provinsinya sekalipun.

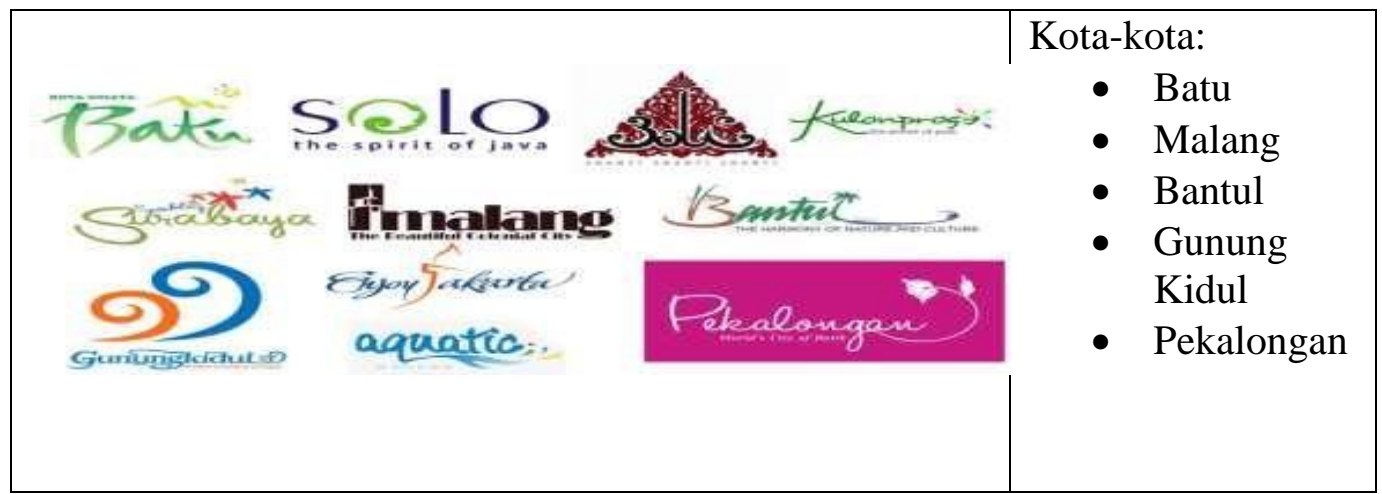

Sumber : Google Image

\section{Gambar 4. Beberapa contoh Penggunaan merek oleh daerah}

Mulai disadari bahwa dibutuhkan Payung Merek (brand Umbrella) dengan tema desain yang sama untuk strategi promosi merek bangsa. Pemilihan warna, desain dan tema itu bukan untuk pariwisata yang seragam. Namun juga harus meng-adopsi kearifan lokal dan nilai-nilai moral lokal yang khas ditiap daerah. Analogi sederhana, dalam merek produk otomotif, Toyota sebagai contoh. Toyota memproduksi tiap tahun ratusan varian produknya (Yaris di Indonesia akan berbeda merek di negara lain). Varian produk dari kelas bawah, menengah hingga kelas mewah. Namun kondisi sederhana yang ditampilkan oleh Toyota adalah ditiap varian, lekukan desain, pilihan varian warna dan spesifikasi standar yang ada dalam mobil akan mencirikan satu janji merek utama: TOYOTA. Bahwa varian apapun yang diproduksinya akan membawa Logo Toyota. Tindakan global Dan berpikir secara lokal (think globaly, act localy)adalah semangat untuk pemasaran merek bangsa. Ada kesadaran kolektif untuk menampilkan Indonesia dengan satu suara tanpa mengurangi keunikan masing-masing daerah. Pada hasil ulasan (review) yang dilakukan oleh Kemenpar pada penelitian sebelumnya diperoleh opsi kebijakan untuk membuatkan payung merek (umbrella brand) bagi pusat dan daerah. Demi mendukung rencana filosofis dan strategis yang telah ditetapkan pada kebijakan merek bangsa ini. Beberapa hal positif yang telah dilakukan oleh Kemenpar adalah mengadopsi umbrella brand ini pada tempat, 
even (perhelatan) dan slogan kampanye promosi turunan. Beberapa contoh berikut implementasi kebijakan merek bangsa dengan tema kampanye berpayung.
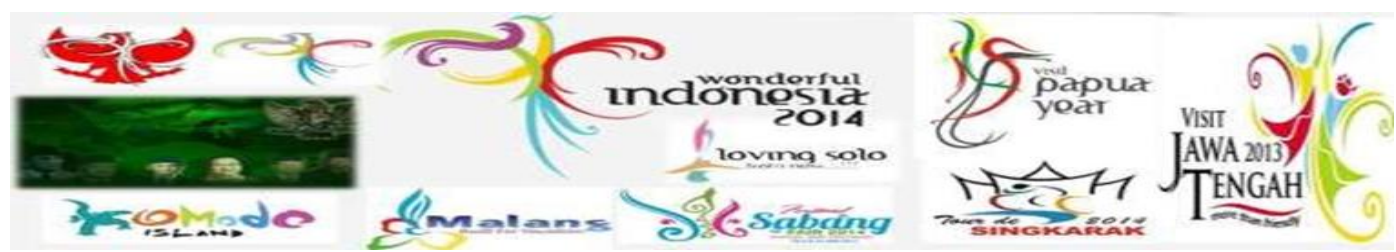

Sumber : Diolah dari Image Google

\section{Gambar 5: Tema Umbrella Brand oleh beberapa daerah yang menginduk pada merek bangsa}

Lalu bagaimana perkembangan wisatawan mancanegara untuk kembali ke Indonesia?. Kebijakan Pariwisata Visit Indonesia Year 2008 dapat dikategorikan gerak langkah proaktif pemerintah untuk menggiatkan kembali sektor pariwisata yang pernah menjadi primadona penerimaan devisa negara nomor 3 (ketiga) setelah pajak dan pertambangan (pada era tahun 1990an). Namun hal ini bukan jalan mulus mengingat potensi pariwisata Indonesia dianggap memiliki kesamaan produk dengan negara-negara dalam skala regional (baca:

ASEAN)

\section{d. Daya Saing Pariwisata Nasional Vs. Regional}

Enam belas tahun yang lalu (1998 Tourism Authority of Thailand), Thailand mendahului penggunaan merek bangsa untuk meningkatkan promosi pariwisata negaranya. Pada perkembangannya pada tahun 2006, Thailand menggunakan merek "The Unforgettable Thailand". Merek bangsa Amazing Thailand digunakan lebih dulu sejak tahun 1998. Namun tema pada tahun 2006 tenggelam, karena merek bangsa Amazing lebih mampu membuktikan bahwa Thailand adalah 'luarbiasa' bagi wisatawan dari seluruh dunia. Pariwisata adalah industri jasa dengan I nsentif tenaga kerja yang tinggi. Dalam mendorong perekonomian, pariwisata dianggap memiliki multiplyer effect pemerataan pembangunan. Sebuah studi dari Malardalen University menyatakan bahwa kuliner, buahbuahan, tumbuh-tumbuhan dan bahan baku makanan memiliki kualitas yang lebih baik. Keunggulan kompetitif Thailand di bidang pariwisata memiliki evaluasi pariwisata internasional sebagai negara "value for money". Singapura (tahun 2004) dan Malaysia (tahun 2005) juga melakukan branding / merek bagi bangsanya. Singapura dengan "Uniquely Singapore", Keunikan: kecil, bersih, kompak, stabil, aman dan menjanjikan bagi wisatawan budaya kosmopolitan. Malaysia dengan "Truly Asia", menjadi salah satu promosi pariwisata internasional yang sukses. Malaysia didukung oleh situasi politik terkendali dan stabil (secure \& Safety). Vietnam menggunakan hidden charm atau 
"pesona tersembunyi" untuk tema merek bangsanya. Pilipina juga memiliki merek mereka sendiri dengan "Wow Philippine ".

Pada capaian regional, kebijakan merek bangsa masing-masing negara ASEAN terbukti ampuh menekan ekses diluar politik terhadap perkembangan politik bangsanya. Thailand walaupun didera kudeta militer dan kejatuhan Perdana Menteri-nya, plus demonstrasi tiada henti mampu memisahkan area politik dan pariwisata. Terbukti walaupun demonstran menduduki obyek-obyek vital, wisatawan masih dapat menikmati keluarbiasaan negara ini. Demikian pula Malaysia yang mampu menjaga stabilitas politik sebagaimana Singapura juga stabil dari pergolakan. Malaysia dan Singapura yang ditopang kondisi keamanan dan kenyaman serta sanitasi yang baik penunjang Pariwisatanya. Perlu diingat kembali formulasi bahwa Pariwisata berkembang karena 3S (Sun, Sea dan Sand) telah berubah paradigma menjadi Safety, Security dan Sanitation. Dimana ketiga negara tersebut diatas telah menjanjikan $3 \mathrm{~S}$ tersebut kepada wisman yang masuk ke negaranya. Pariwisata Indonesia masih terpaku pada kedigdayaan Bali sebagai magnet wisman ke Indonesia. Sehingga faktor eksternal pengembangannya lupa untuk diantisipasi. Contoh sederhana, bila terjadi demonstrasi anarkis di Indonesia akan langsung menurunkan minat wisman untuk masuk ke Indonesia. Area politik dan kegiatan politik berdampak kepada operasional kepariwisataan. Karena terjadi ketidakpastian jadwal, kemacetan jalan dan dampak kenyamanan lainnya (faktor 3S gagal dipenuhi).

\begin{tabular}{|c|c|c|c|c|c|}
\hline $\begin{array}{c}\text { Industry } \\
\text { Competitiveness Index }\end{array}$ & Indonesia & Malaysia & Thailand & Singapore & Philippines \\
\hline Rep. Offices \& & \multirow{2}{*}{9 rep office } & ff \& & \multirow{2}{*}{18 brand office } & \multirow{2}{*}{22 brand office } & 18 bra \\
\hline Marketing in 2008 & & 10 rep off & & & 2 Rep office \\
\hline Total Inbound Tourist 2010 & $7.0 \mathrm{mil}$ & $23.64 \mathrm{mil}$ & & & $3.52 \mathrm{mil}$ \\
\hline Growth Inbound & \multirow{2}{*}{$10.74 \%$} & \multirow{2}{*}{$3.94 \%$} & \multirow{2}{*}{$12.63 \%$} & \multirow{2}{*}{$20.22 \%$} & \multirow{2}{*}{$16.68 \%$} \\
\hline Tourist 2009-2010 & & & & & \\
\hline Average & \multirow{2}{*}{ USD 970.9} & \multirow{2}{*}{ USD 850} & \multirow{2}{*}{ USD 1,076.6 } & \multirow{2}{*}{ USD 1,088 } & \multirow{2}{*}{ USD 1,594 } \\
\hline Expenditure/visit 2010 & & & & & \\
\hline Promotion Expenses & USD 15 mil & USD 100 mil & USD 85 mil & USD 90 mil & USD 8.5 mil \\
\hline Tourism Receipt & USD 5,3 bil & USD 14 Bil & USD 15 Bil & USD 8.66 bil & USD 4.93 bil \\
\hline
\end{tabular}

Selanjutnya bagaimana pertumbuhan ini dilihat dari kajian keberhasilan merek bangsa diantara negara-negara ASEAN. Berikut tabel yang menjelaskan indeks capaian keunggulan beberapa contoh negara ASEAN. Dari grafik dan tabel diatas didapat aspek daya saing yang berakar kepada capaian regional dan nasional. Menurut narasumber kemenpar, truly asia sebagai benchmark keberhasilan branding pariwisata. Karena dari hasil capaian output wisman yang 
berkunjung ke Malaysia bisa menembus angka 24 juta wisman datang ke Malaysia. Bila disandingkan dengan Ultimate in Diversity maka, truly asia merupakan keberhasilan promosi merek bangsa pariwisata Malaysia sebagai indikator pembanding dengan kategori berhasil. Pada perkembangannya untuk Indonesia hasil 2010 (pada tabel sebelumnya) dapat dibandingkan dengan capaian pada tahun 2012 sebagaimana berikut ini:

Tabel 3. Profil Wisatawan Mancanegara masuk Indonesia (2012)

\begin{tabular}{|c|c|c|c|}
\hline Karakteristik & Sub & Total & $\%$ \\
\hline Devisa & & $\begin{array}{l}\text { USD } \\
9,120,850\end{array}$ & \\
\hline $\begin{array}{l}\text { Jumlah Total } \\
\text { wisman }\end{array}$ & & $8,044,462$ & \\
\hline \multirow[t]{2}{*}{ Jenis Kelamin } & Laki-laki & $5,366,423$ & 66.71 \\
\hline & Perempuan & $2,678,039$ & 33.29 \\
\hline \multirow[t]{3}{*}{ Akomodasi } & Hotel & $6,350,697$ & 79 \\
\hline & Famili & 499,687 & 6 \\
\hline & lainnya & $1,194,078$ & 15 \\
\hline \multirow[t]{6}{*}{ Usia } & $15-24$ & 837,712 & 10.41 \\
\hline & $25-34$ & $2,180,111$ & 27.1 \\
\hline & $35-44$ & $1,959,592$ & 24.36 \\
\hline & $45-54$ & $1,442,473$ & 17.93 \\
\hline & $55-64$ & 778,399 & 9.68 \\
\hline & $>64$ & 389,412 & 4.84 \\
\hline \multirow[t]{4}{*}{ Tujuan Perjalanan } & Liburan & $4,744,009$ & 58.97 \\
\hline & Bisnis & $2,447,344$ & 30.42 \\
\hline & MICE & 169,243 & 2.1 \\
\hline & Dinas & 118,121 & 1.47 \\
\hline \multirow[t]{4}{*}{ Pekerjaan } & Profesional & $2,706,240$ & 33.65 \\
\hline & Manajer & $1,831,933$ & 22.77 \\
\hline & Staff & $1,224,613$ & 15.22 \\
\hline & Pelajar & 835,861 & 10.39 \\
\hline \multirow[t]{3}{*}{$\begin{array}{l}\text { Moda } \\
\text { Transportasi }\end{array}$} & Udara & $5,754,847$ & 71.54 \\
\hline & Laut & $2,241,661$ & 27.87 \\
\hline & Darat & 47,955 & 0.6 \\
\hline Lama Tinggal & & 7.70 days & \\
\hline \multirow[t]{2}{*}{ Belanja Wisman } & Per hari & USD 142.69 & \\
\hline & Per & USD & \\
\hline
\end{tabular}




\begin{tabular}{|l|l|l|l|} 
& Kunjungan & $1,118.28$ & \\
\hline
\end{tabular}

Sumber : Kementerian Pariwisata 2014 (internet data)12 
Tahun 2009-2012, dapat dikatakan sebagai tahun kebangkitan pariwisata Indonesia. Terhitung pada tahun inilah terjadi peningkatan signifikan terhadap arus wisman masuk menjelajahi Indonesia. Setelah terpaan travel warning, Bencana, Penyakit menular dan terorisme, angka wisman didominasi oleh tourist laki-laki (66\%). Gerbang masuk Indonesia melalui Jakarta, Batam dan Denpasar. Seorang pebisnis dari Eropa yang diwawancarai menyatakan, ia belum membawa istrinya datang ke Indonesia, lebih kepada alasan pekerjaan. Ia merasa perjalanan dinasnya tidak etis bila membawa istri (diskusi dilakukan selama perjalanan terhadap penumpang asal Italia yang sudah 6 kali berkunjung ke Indonesia namun belum pernah membawa keluarganya/istrinya ke Indonesia).

Indonesia masih melakukan koreksi, namun dalam perbaikan sebagian dari citra Indonesia di tingkat lokal, regional dan global. Pada saat negara-negara Asia dan ASEAN mengambil nama-nama Internasional dalam membina pariwisata: Hongkong dengan Walt Disney Hong Kong, Malaysia dengan Lego Land, Universal Studios Singapore dan Thailand dengan Cartoon Network. Indonesia tetap konsisten mengembangkan wisata alam dan budaya. Menurut narasumber peneliti pariwisata, terdapat beberapa temuan yang menekankan kepada adanya kesulitan merek bangsa untuk terproyeksikan dalam kehidupan sehari-hari. Kekhususan Indonesia dengan mengangkat tema Ultimate in Diversity. Kesulitan seperti contoh: bila di Singapura terdapat papan-papan peringatan atau tanda penunjuk jalan memiliki setidaknya tiga bahasa (Inggris, Melayu dan Cina atau juga terdapat tanda peringatan berbahasa tamil). Begitu juga dengan negara Malaysia. Bertolak belakang di Indonesia, Bahasa Indonesia mendominasi pengumuman, dengan Bahasa Inggris hanya tersedia di Bandara Internasional atau beberapa Mall berkelas.

Contoh lainnya yang diberikan narasumber, bila dikaitkan dengan merekmerek kota/kabupaten dan provinsi, banyak tagline yang dapat dikategorikan melebihi tema nasional. Misalnya: Jogja "Never ending Asia". Atau tema yang memudar dengan semangat brand-nya. Jakarta dengan "enjoy" akan sangat sulit menikmati Jakarta dengan kesemrawutannya. Bandung dengan Paris van Java, tentu nostalgia Eropa di Bandung mulai tergerus pembangunan dan kepadatannya saat ini. Malaysia tetap jaya dan sukses menjadi truly asia. Singapura menuju kampanye digital dengan yoursingapore.com. Thailand meski tampil dengan tema "Amazing", terus menggunakan promosi pariwisata yang sama dengan yang sudah ada. Hal ini dapat dimengerti karena Thailand saat ini sedang mengalami gejolak internal yang terus bergejolak di arena politik. Tetapi ada pemain baru, yaitu Kamboja dan Laos di mana dalam dua tahun terakhir menggunakan merek bangsa dengan tema kampanye global dan menjadi kompetitor unggulan yang akan merusak porsi wisatawan asing untuk juga berkunjung ke Indonesia. Negara-negara ASEAN tengah mempersiapkan diri dalam menyongsong tahun 2015. Dengan ditetapkannya AFTA yang menitikberatkan kepada politik perdagangan regional yang mengikat. AFTA ASEAN Free Trade Area mengundang negara-negara yang tergabung di dalamnya untuk mengintegrasikan diri dalam semangat kumpulan masyarakat Asia Tenggara. Dengan kampanye pemasaran pariwisata ASEAN "Feel The warmth". 
Namun dalam tingkat lokal (baca: daerah) Indonesia harus mengejar ketertinggalan dalam konteks ini. Sehingga Indonesia siap menghadapi AFTA dan terpaan globalisasi yang kini berjalan. Sebagaimana tertulis pada awal, pada akhirnya negara-negara hidup damai rukun namun harus memiliki lokal identitas yang kolektif dalam ranah kebangsaan dan kenegaraan (kedaulatan).

\section{SIMPULAN}

Dapat disimpulkan dari uraian sebelumnya bahwa, merek bangsa saat ini sedang terus digiatkan baik dalam persepsinya dimata masyarakat global maupun regional. Kesimpulan berikut mengerucutkan merek bangsa kepada hal-hal berikut ini:

1. Dalam perkembangannya, Pariwisata Indonesia mengalami beragam hambatan baik yang berasal dari internal (terorisme, radikalisme, Bencana alam) maupun eksternal (wabah penyakit menular, perang, arab spring dan kecelakaan penerbangan).

Namun apapun hambatan-nya, kebijakan merek bangsa selayaknya dilanjutkan dengan beberapa perbaikan dan sinerjis kebijakan tepat guna bila dibandingkan dengan tanpa melakukan apapun. Kebijakan Inpres No. 16 Tahun

2005 tentang Kebudayaan dan

Pariwisata ini layak diapresiasi karena secara dampak finansial bukanlah segalanya. Namun ditelisik dari nilai strategis dan filosofis nan terkandung didalamnya lebih mendasari dikeluarkannya inpres tersebut.

2. Dalam implementasi kebijakan, merek adalah janji atau mantra yang akan diterima oleh konsumen untuk menikmati produk yang disajikan. Brand Equity yang dimiliki masingmasing kota bersifat eksklusif terhadap kedaerahannya, namun tetap menginduk pada tema nasional, dalam aplikasi merek daerah beragam. Sehingga dapat dijabarkan bahwa dalam teori paradigma filosofisstrategis, merek bangsa mengadopsi semangat Bhineka Tunggal Ika. Dalam rambu-rambu pluralisme bukan asimilasi . Dengan tema yang sangat berbeda tersebut, dapat ditarik simpulan bahwa kampanye Ultimate in Diversity telah menuju kepada umbrella brand yang menempatkan merek varian berjenjang.

3. Isu terbaru selain 3S (Sun, Sea and Sand) yang dulunya menjadi primadona pariwisata dunia telah berubah menjadi kondisi ideal pariwisata yang menjual Safety, Security dan Sanitation. Karena banyaknya tekanan terhadap keselamatan, kesehatan dan Kenyamanan warga asing di negara lain. Bertaburnya Travel Warning yang dilontarkan negara tetangga terhadap Indonesia wajib dimaknai sebagai kebijakan pemerintah wajib menjaga nama baik merek bangsa pariwisata di mata internasional. 


\section{OPSI KEBIJAKAN}

Kalimat opsi kebijakan disini lebih kepada memberikan pilihan kebijakan alternatif bila kebijakan ini akan di revitalisasi oleh pemangku kepentingan. Dalam Nilai filosofisstrategis, Implementasi kebijakan dan daya saing pariwisata Indonesia belum dapat dikategorikan belum berhasil dan perlu diganti. Namun persoalan bangsa bila disandingkan dengan kebijakan merek adalah persoalan yang lebih kompleks dan multidisplin. Sehingga kajian lanjutan dan perspektif yang lebih luas diharapkan dapat dilakukan dimasa depan.

Berikut opsi kebijakan terkait paparan yang dijadikan fokus penelitian ini:

a. TRANSISI menuju demokrasi dan ultima dalam perbedaan selayaknya gadogado, ciri-khas sayur mayur, bentuk ciri ketupat dan bumbu kacangnya masih nampak dalam sajian piring (analogi ini diperoleh dari hasil FGD yang dilaksanakan di Jakarta Agustus 2014). Opsi Kebijakan hasil FGD ini memang masih terasa sulit diaplikasikan. Mengingat asimilasi budaya telah berlangsung lama dan membekas. Sehingga Pancasila dianggap "blender" kebudayaan oleh sebagian narasumber. Semangat bhineka tunggal ika seharusnya lebih optimal kepada pluralistik bukan asimilasi. Opsi Kebijakan 1: Program pluralis-multikultur: dalam semangat, visi dan misi berkehidupan dalam masyarakat yang tumbuh dan berkembang dalam keberagaman tetap berkesatuan (unity in diversity).

b. Walaupun Pulau Komodo dan Raja Ampat sedang giat-giatnya dipromosikan namun devisa melalui pariwisata masih didominasi Bali sebagai Focal Point. Opsi Kebijakan 2 : perbanyak jumlah obyek wisata (daerah tujuan wisata DTW) agar lama tinggal wisatawan dapat melebihi 7 hari. Infrastruktur menuju DTW yang enclave (bersinggungan) dengan Bali terus digali dan dikembangkan. Termasuk daerah Indonesia timur yang belum tergali. Terkait rekomendasi implementasi merek bangsa antar pusat - daerah opsi kebijakan turunannya adalah: Adanya sinerjitas antara pemerintah daerah dengan pemerintah pusat. Bila 500-an kota dan kabupaten di Indonesia bersatu dalam pembiayaan merek bangsa dan mengumpulkan 1 milyar per kabupaten/kota, maka angka yang diperoleh mampu mengurangi beban pembiayaan nasional dalam promosi merek bangsa secara

Internasional. Opsi kebijakan turunan lainnya adalah : pelibatan pihak swasta (private sector stakeholder) baik lokal maupun nasional dalam pengembangan merek bangsa ini. Keterlibatan swasta dalam implementasi kebijakan lebih membumi bila dibandingkan dengan kebijakan yang sifatnya Top-Down. Pihak swasta juga dianggap memiliki rasa kepemilikan yang sama terhadap merek bangsa.

c. Opsi Kebijakan 3: Re-inventing Indonesia dalam merek bangsa. Persaingan regional dan global telah berlangsung lebih dari satu dekade. Singapura telah menggandeng merek global dalam DTW-nya demikian pula Thailand dan Malaysia (lihat : Universal studio, Lego land dan cartoon network). Bahkan 
Singapura telah mengadopsi himbauan kepemilikan dalam mereknya: yoursingapore.com. Kandungan digital dan berteknologi tinggi menjadi tema kampanye merek bangsanya. Merek bangsa adalah kebijakan multi-tahapan. Walau demikian re-inventing ini bukan untuk mengganti gambaran besarnya, lebih kepada internalisasinya. Agar Ultima dalam perbedaan ini memang terproyeksikan didalam kehidupan sehari-hari. Dinilai menarik oleh bangsa lain sehingga merek bangsa ini lebih optimal dalam evaluasinya kedepan.

\section{DAFTAR PUSTAKA}

Aminudin, Muhamad. 2007. Evaluasi Rencana Lokasi Pemindahan Terminal Induk Km. 6 Banjarmasin. Yogyakarta: MKPD Universitas Gadjah Mada. (Unpublished)

Ave, J. 2006. Pengukuhan Wisuda Universitas Sahid . Sebagai Pembicara Kunci Indonesia

Cromwell,Thomas. 2007, Why Nation Branding Is Important For Tourism, http://www.eastwestcoms.com/res_why.ht m. diakses pada bulan Juli 2014

Fang, Yin. 2006. Branding The nation: What is Being Branded. Journal of Vacation Marketing Vol;12 no. 1 Brunel Business School, Brunel University $U K$

Gunawan Muhamad, Catatan Pinggir-Caping: Westphalia, Majalah TEMPO edisi cetak edisi 15-21 September 2014

Kaneva, N, \& Popescu, D, 2011. National identity lite: Nation branding in post Communist Romania and Bulgaria, International Journal of Cultural Studies , Volume 14(2): 191-207 DOI: 10.1177/1367877910382181

Ring of Fire, Kompas Gramedia Group, 2012

Riwanto Tirtosudarmo, 2010. Mencari Indonesia 2, Batas-batas Rekayasa Sosial, LIPI.

Prucpairojkul, Piyada dan Triamsiriworakul. 2008. Thailand's Nation Branding: A Study of Thai Nation-Brand Equity and Capabilities. Master Thesis, Thailand: Malardalen University.

Varga,S. 2013. The politics of Nation Branding: Collective identity and public sphere in the Neoliberal State, University of Memphis USA. SAGE Philosophy and Social Criticism 39(8) 825-845 